
fusion devices. Ongoing efforts in data generation for model development purposes will also be briefly discussed.

The materials to be considered will be those associated with the American Society of Mechanical Engineers (ASME) Boiler and Pressure Vesse1 Code, Case $N-47$ and are as follows: types 316 and 304 stainless steel, Fe-2 1/4 Cr-1 Mo steel, and alloy $800 \mathrm{H}$.

Specific examples used here to show environmental interaction and the complexities of time-dependent fatigue involve liquid sodium, high vacuum, air, impure helium, and irradiation danage.

\section{ENVIRONMENTAL INTERACTION AND TIME-DEPENDENT} FATIGUE IN FAST BREEDER REACTOR SYSTEMS

High-purity liquid sodium is the heat transfer medium or core coolant for many planned as well as operating fast breeder reactor systems. In part this results from its excellent heat transfer characteristics and lack of deleterious effects on the mechanical properties of structural steels, provided that the oxygen and carbon contents, ${ }^{2}$ as well as other liquid-metal embritting elements such as lead, tin, and antimony, are carefully controlled. 3 However, factors such as composition of the individual structural allos, exposure temperature and time, etc. must also be laken into a ccount. 4

In addition to the chemical effects, the physical effects of sodiun, such as good heat transfer properties, must be considered. The effects of reactor trips as well as sodium streams that are at different temperatures mix while iapinging upon component surfaces and produce local differences in temperatures. These effects may produce time-dependent or independenc fatigue damage depending upon their frequency. Reactor trips (power changes, startups, or shutdowns) are relatively infrequent, perhaps with up to 1000 occurring over the design lifetime of the plant. However, large changes in stress level can occur with resultant low-cycle creepfatigue damage possible. Impingement of sodiun at different temperatures or thernal striping on the surface of above-core structural components or at mixing tees produces a possible highcycle fatigue ( $10^{9}$ cycles) problen. In liquid-metal fast breeder reactor systems these combinations of high- or low-cycle tinedependent Eatigue interactions are addressod by particular care in design, by proper selection of materials, and by extensive material characterization programs. 


\section{Austenitic Stainless Steels}

Types 304 and 316 austenitic stainless steels are used extensively as vesse1, piping, core suppurt, and heat exchanger materials in fast breeder reactor systems. 5 These components can accrue creep-fatigue danaje as a consequence of exposure to thermal transients, as discussed above. For these reasons a long-term creepfatigue program has been and continues to be under way at Argonne National Laboratory. The objective of this program is to generate data on types 304 and 316 stainless steel from specimens with failure times ranging to three years. Figure 1 summarizes much of the data currently available from this program plotted in a " $t-\mathrm{N}_{\mathrm{f}}$ " or log total test time-vs-log cycles to failure diagran for various strain ranges and tensile hold times. 6 A11 the data came from tests conducted in air and in strain control with the indicated hold periods at the peak tensile strain point on the hysteresis

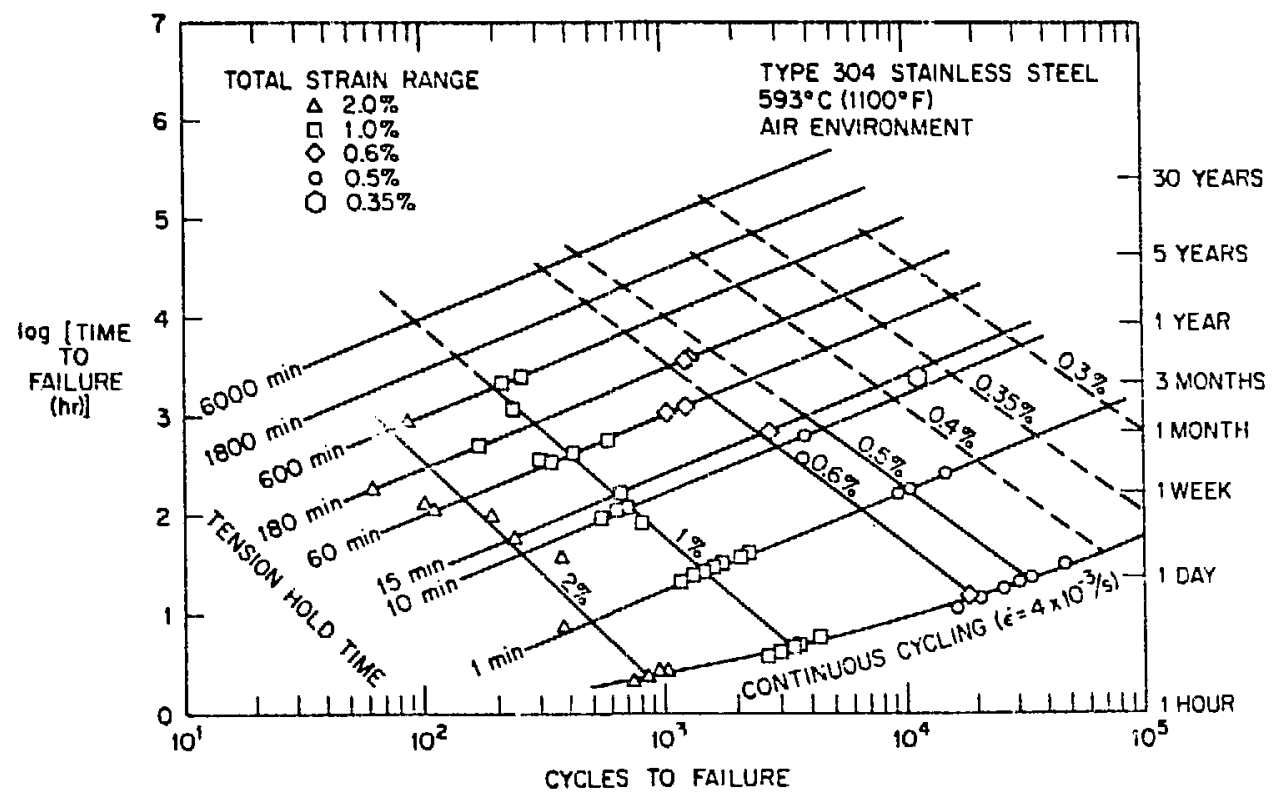

Fig. 1. Time to failure vs cycles to failure showing the influence of tensile hold times on the fatigue life of type 304 stainless steel. Source: C. R. Brinkman, V. K. Sikka, M. K. Booker, "An Overview of the U.S. Programs on Properties of Primary Circuit Materials," pp. 13-23 in Specialist leeting on Prinary Circuit Materials Including Environtiental Effects, IWGFR/22, International Atonic Energy Arency/International Working Group on Fast Reactors, Bergisch Gladbach, Federal Republic of Germany, October 17-21, 1977. 
loop. The data show a continued degridation in fatigue life with increasing duration of hold tine with no indication of saturation of the hold-time effect.

Envifonments that limit or frowis surface oxidation at high temperatures typically result in hisk: jmprovements in the continuous cycle life of types 304 and 316 stainless steel. Comparison of data generated from specimens tested in high vacuum with air data indicated an improvement in cycle life with factors ranging from 3 to 5 at strain ranges from 0.5 to $2.0 \%$. In sodium with 1 to 2 ppm oxygen a similar beneficial effect is noted in comparison with data generated in air particularly at low strain ranges. This beneficial effect of sodium has tentatively been attributed to improved crack nucleation resistance, as fewer surface cracks are noted on post-test examination for specimens tested in sodium in comparison with specimens subjected to identical test parameters in air. 8 on the other hand, a decrease in crack growth rates is also observed in compact tension specimens tested in sodium in comparison with those similarly tested in air. ${ }^{2}$

Figure 2 compares strain-controlled low-cycle fatigue data for type 304 stainless steel generated both with and without tensile hold times at $593^{\circ} \mathrm{C}$ and at a single strain range. The data show

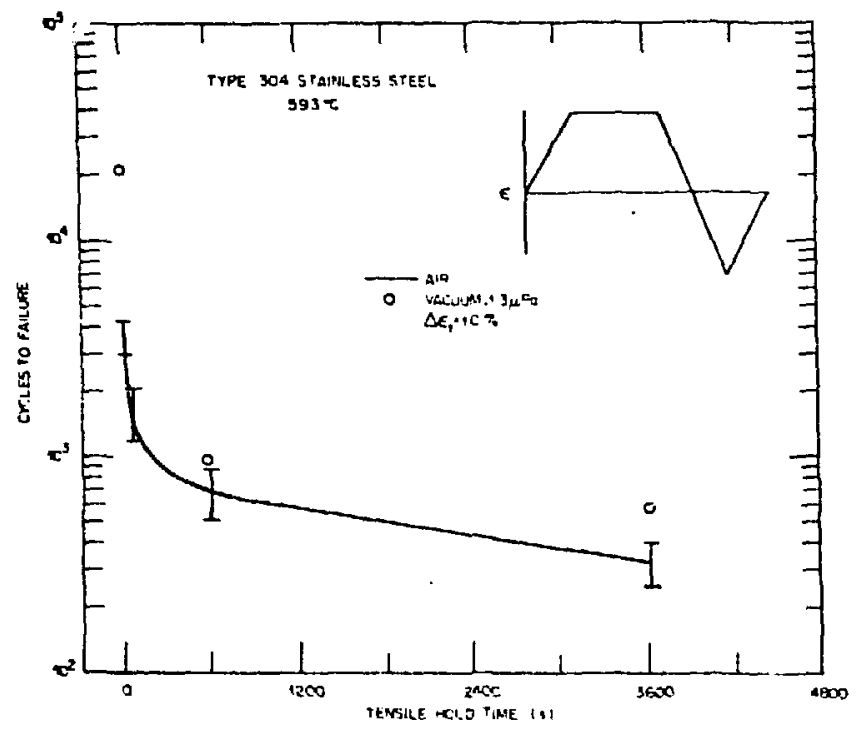

Fig. 2. Degradation of fatigue life resulting from tensile hold times becones nearly the same as the length of the hold period increases for high vacuum and air environments. Source: P. S. Maiya, "Effects of Waveshape and UltraHigh Vacuun on Elevated Temperature Low-Cycle Fatigue in Type 304 Stainless Stee1," subuitled to Materials Science and Enginecring. 
that la: differences exist for cycle life between continuous cycla lata $\left(\dot{E}=4 \times 10^{-3} / \mathrm{s}\right)$ generated in air and under high vacuun $\left[\left(1.3 \times 10^{-5} \mathrm{~Pa}\left(10^{-8}\right.\right.\right.$ torr $\left.)\right]$, However, these differences tend to be minimal as the length of the tensile hold time increases. A similar conclusion has been reached in comparing limited results of strain-contralled tests conducted on type 316 stail.less steel tested in high purity sodium. 8 The significance of waveform in producing creep damage that leads to intergranular fracture in type 304 stainless stee ${ }^{7}$ is shown in Fig. 3. Ilere the ratio of cycle iife in vacuum to cycle life in air is plotted against plastic strain range. Tensile strain-controlled hold times or triangular "slow-fast" ramp rates lead to intergranular fracture with the result that high vacuum tends to be less important than when the waveform imposed leads to transgranular fatigue crack propagation. These results tend to demonstrate a true creepfatigue effect fot this material. That is, degradation in cycle life under conditions that produce considerable intergranular cavitation and crack propagation primarily results from creep damage rather than environmental interaction, as has been suggested by several investigators.9,10 Sadananda et al.11 similarly have concluded from crack growth studies conducted on several austeni$t$ ic stainless steels tested in vacuum $\left[1.3 \times 10^{-4} \mathrm{~Pa}\right.$ (10-6 torr)] and in air tirat enhanced crack growth under hold times primarily results from creep-fatigue interaction.

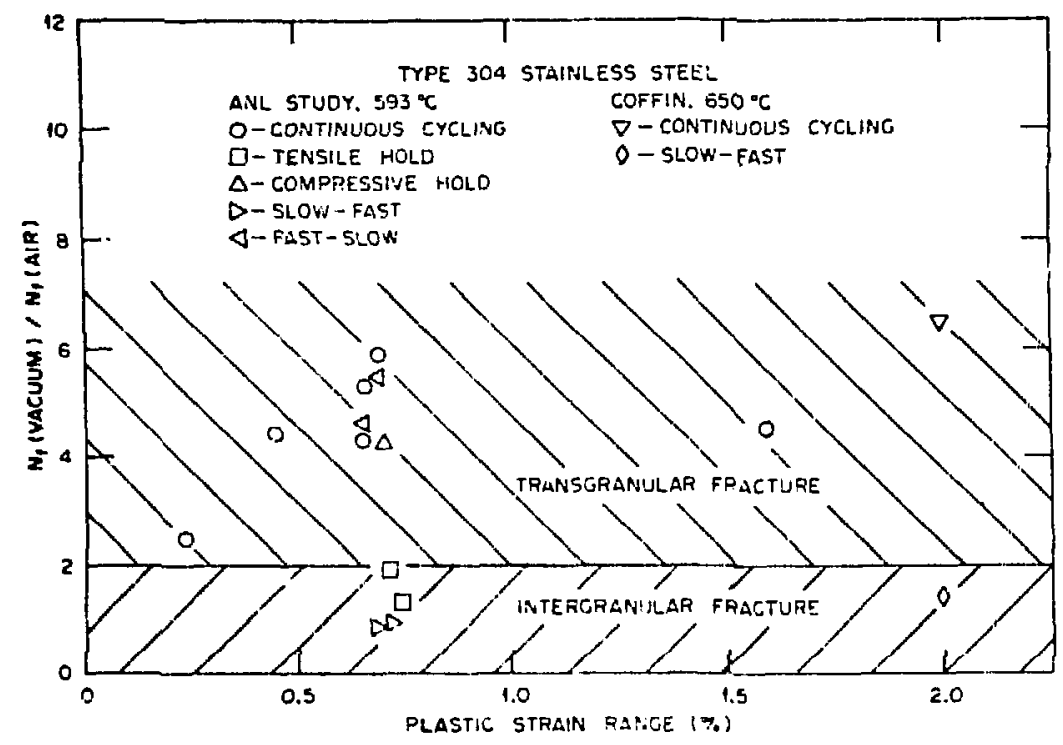

Fig. 3. Effect of waveshape and environment on fracture mode. Source: P. 5. Maiya, "Effects of Waveshape and Ultra-ligh Vacuun on Elevated Temperature Low-Cycle Fatigue in Type 324 Statnl, ". Fieel," subsitced to Naterials Science and Kriginueing. 
Recently investigators conducting strain-controlled exploratory fatigue tests on the austenitic stainless steels in both the United States and Japan 12 have been imposing hold periods on the hysteresis loop each cycle at locations other than peak tensile or compression values. An example of this effort is shown in Fig. 4 for type 304 stainless steel tested at $650^{\circ} \mathrm{C}$ in air ${ }^{12}$ llere a strain hold period of $0.17 \mathrm{~h}(10 \mathrm{~min})$ for the example shown is introduced at the same point on the hysteresis loop each cycle until failure. These tests are being conducted to generate a data base for mode1. substantiation or development with hold periods imposed at locations such as zero stress, as shown, or at points on the hysteresis loop where little or no stress relaxation occurs. Data genorated in air of the type shown in Fig. 4 tend to show the following:

1. Tensile hold times at peak strain values are more damaging than compression hold times of equal duration.

2. Hold periods imposed at other locations on the hysteresis loops, such as at zero stress or zero stress relaxation points, degrade fatigue life but not as mich as hold periods imposed at peak tensile strain values.

3. Hold periods imposed on the tension-going side of the loop tend to be more deleterious than those imposed on the compressiongoing side.

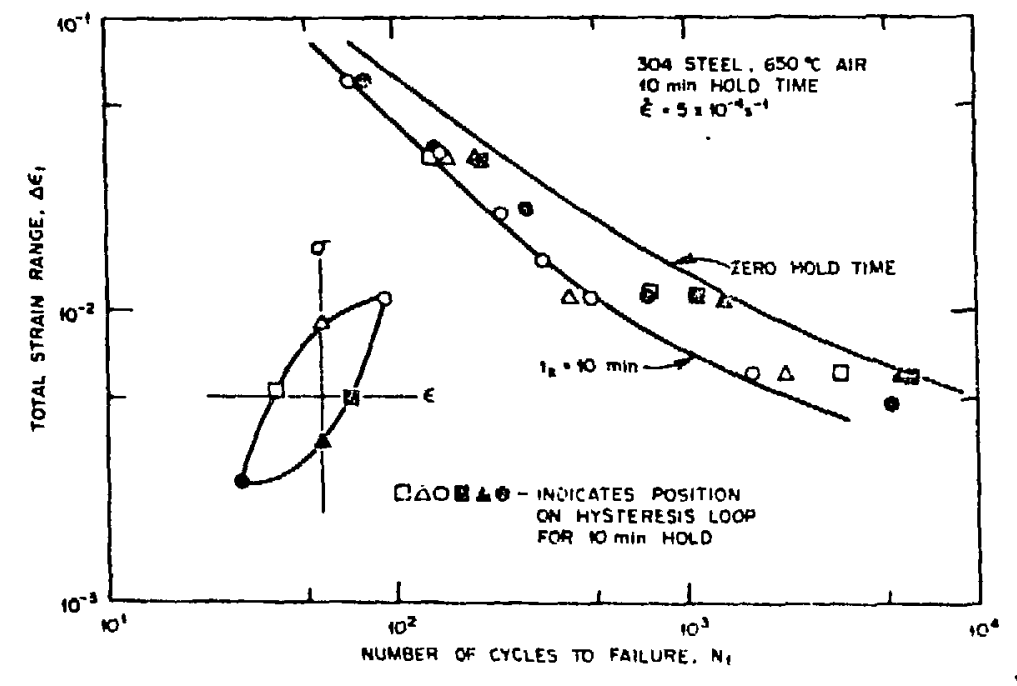

Fig. 4. Results of Japanese exploratory creep-fatigue tests. Source: Y. Asda and S. Mitsuhashi, "Creep-Fatigue Interaction of 304 and 316 Stainless Steels in Air and Vacuun," paper presented at 4 th International Conference on Pressure Vessel Technolagy, London, Englank, liay 19-23, 1980. 
Another area of current interest for design of fast breeder reactor systems is fatigue crack propagation. Recent results have shown that a phenomena called "accelerated crack propagation" can occur for particular combinations of waveforn, hold-time duration, and perhaps metallurgical state. 13 Figure 5 shows an example for type 316 stainless steel tested in the thermally aged condition before testing at $593^{\circ} \mathrm{C}$. The data show that when intergranular precipitate particles are present, combined static and dynamic

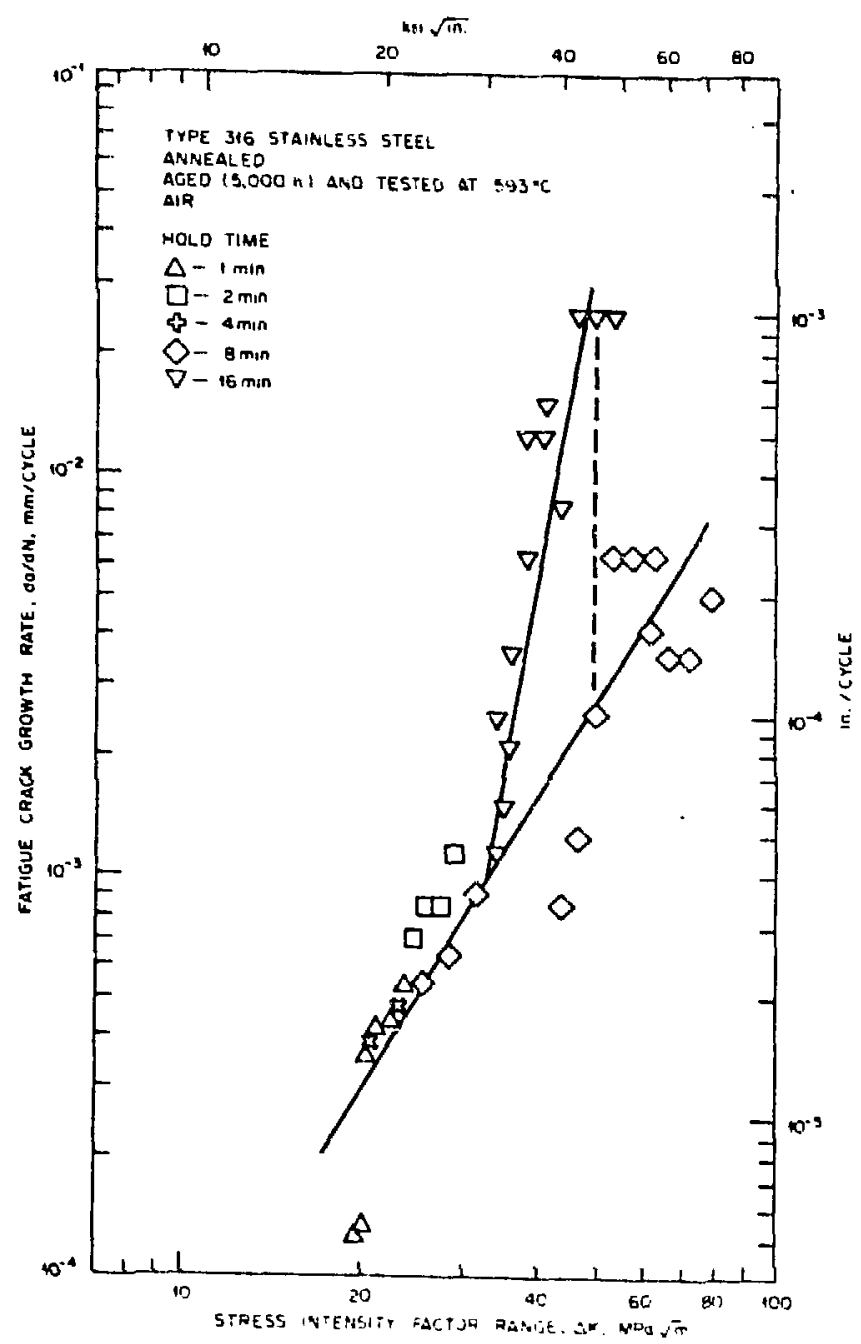

Fig. 5. Accelerated cracl: propagation in solution annealed, thermally aged 316 stainless steel tested at $593^{\circ} \mathrm{C}$. Source: D. J. Hichel and H. H. Smith, "Accelerated Creep-Fatigue Crack Propagation in Thermally Aged Type 316 stainless 5teel," to be published in Act. Metallurgica. 
(zero to cansion loading plus load-controlled) hold periods can lead to th gher crack propagation rates. For the example shown, hold periuds equal to or in excess of $0.27 \mathrm{~h}$ ( $16 \mathrm{~min}$ ) led to accelerated crack propagation rates essociated with intergranular crack propagation. It is thought by some 13 that the increase in crack propagation rate is related to a critical cavity size and spacing assoctated with intergranular carbides. Hovever, other investigators have not noted such a relationship. 14 Further, similar studies conducted on type 316 stainless steel in air at elevated temperatures have shown some evidence of environmental interaction. 14 ongoing test efforts are expected to clarify the role of environment in producing accelerated crack growth behavior In this material.

\section{Fe-2 $1 / 4 \mathrm{Cr}-1$ Mo Steel}

Fast breeder reactors presently in operation, as wel1 as those planned for future operation, make extensive use of $21 / 4 \mathrm{Cr}-1$ No steel as a steam generator material.15 This alloy, which will undergo prolonged exposure at temperatures within the creep range auring a design lifetime of up to 30 years, will be subject to both time-dependent and time-independent fatigue damage. Accordingly, the material has been extensively characterized in the annealed condition for its fatigue properties.16,17 Results from staincontrolled fatigue tests that were conducted in varicus environments over the temperature range of about 370 to $593^{\circ} \mathrm{C}$ on annealed material have shown that time-dependent fatigue lifetime depends upon the influence of the following:

1. environment or oxidation,

2. metallurgical state,

3. waveform and frequency,

4. classical creep damage.

At temperatures within the range of about 371 to $482^{\circ} \mathrm{C}$, tensile and fatigue propertles are dependent upon testing strain rate, primarily because of the effects of dynatic strain aging or interaction solid-solution hardening. 17,18 At temperatures in excess of approxtmately $450^{\circ} \mathrm{C}$, time-dependent fatigue life in air is dependent upon the oxfde scale (Fig. 6) that is forned and upon its behavior when the material is subjected to different waveforms.18, 19 Test data obtained in air and in strain control with either tensile or compressive hold times or wh both tensile and compressive hold periods introduced each cycle have shown the following trends over the temperature range 427 to $593^{\circ} \mathrm{C}$ :

1. Compressive told times are more damaging than tensile holds, particularly at low strain ranges where resistance to crack nucleation governs lifetime (Fig. 7). 

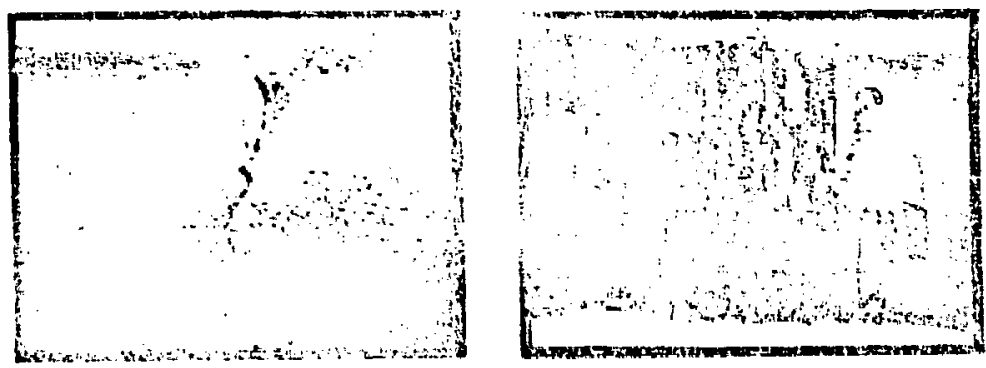

Fig. 6. A low-oxygen environment is a significant factor affecting elevated-temperature fatigue resistance. Surfaces of specinens tested in air show extensive oxidation compared with specimens tested in high-temperature gas-cooled reactor (HTCR) helium.

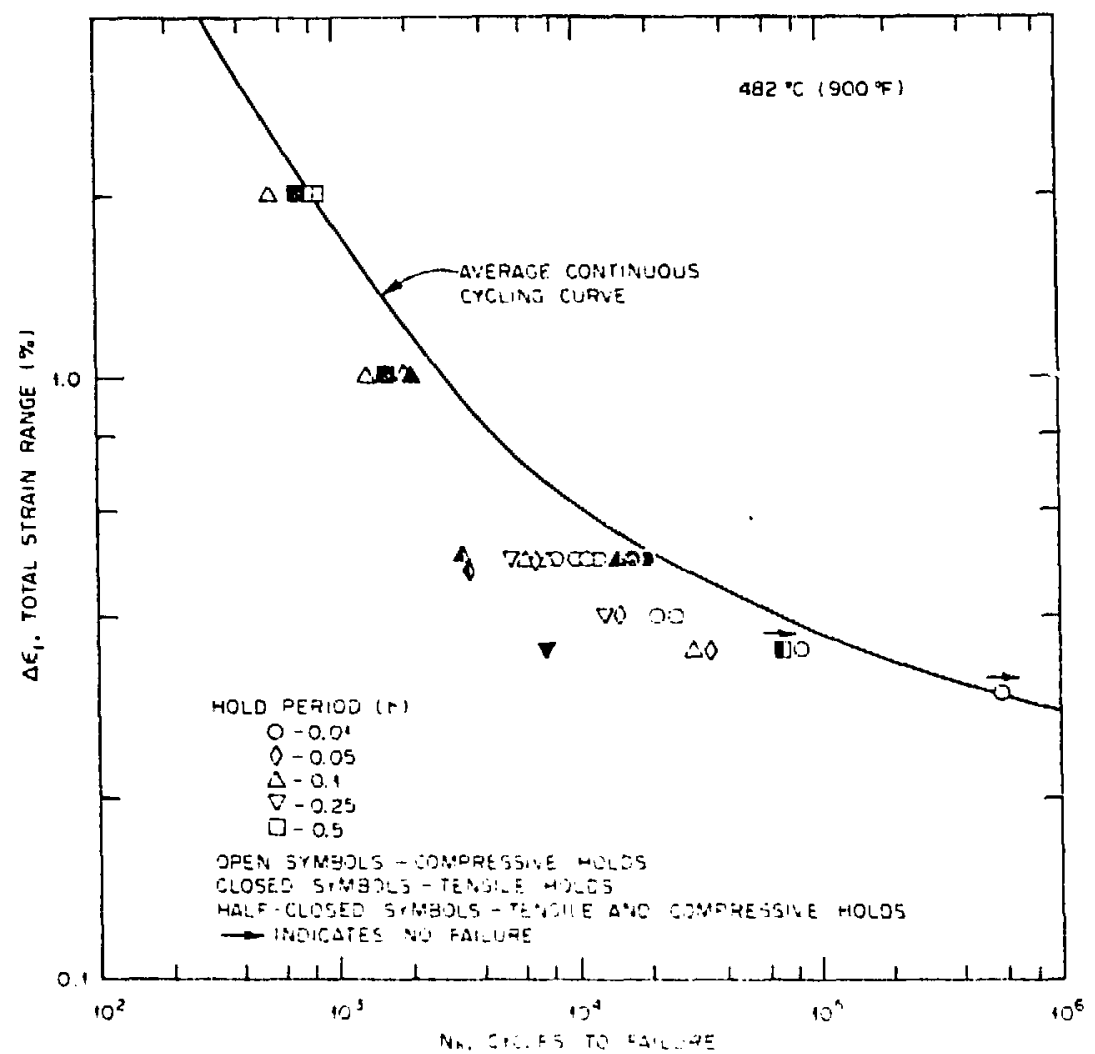

Fig. 7. Results of strain-controlled fatigue tests condlitit on annealed $21 / 4 \mathrm{Cr}_{\mathbf{r}}-1$ Mo steel with various hold periuds. 
2. $\therefore$ cycle with both a tensile and a compressive hold period at wh stain ranges may be more damaging than the cycle with only a teivise or compressive hold with all hold periods of the same duration (Fig. 7).

Not all low-alloy steels that have been tested to date demonstrate this type behavior under cyclic and time-dependent loading conditions. For example, a rotor steel $(1 \mathrm{Cr}-\mathrm{No}-\mathrm{V})$ that was extensively tested 20 indicated that tensile hold times were most damaging. Furthermore, compression holds when introduced into cycies that already contained tension holds were beneficial in that cycle life was improved (fig. 8).

When tests are conducted at $538^{\circ} \mathrm{C}$ or higher in environments that limit or prevent oxidation [e.g., impure or high-temperature gas-cooled reactor (HTGR) helium (Fig. 9) or sodium 2 (Fig. 10)] tensile hold periods become more damaging for cycle life for annealed $21 / 4 \mathrm{Cr}-1$ Mo steel. Further, when a slow-Fast waveform (1.e., $4 \times 10^{-5} / \mathrm{s}$ tension going and $4 \times 10^{-3} / \mathrm{s}$ compression going) was employed in law-oxygen sodium environment tests, grain

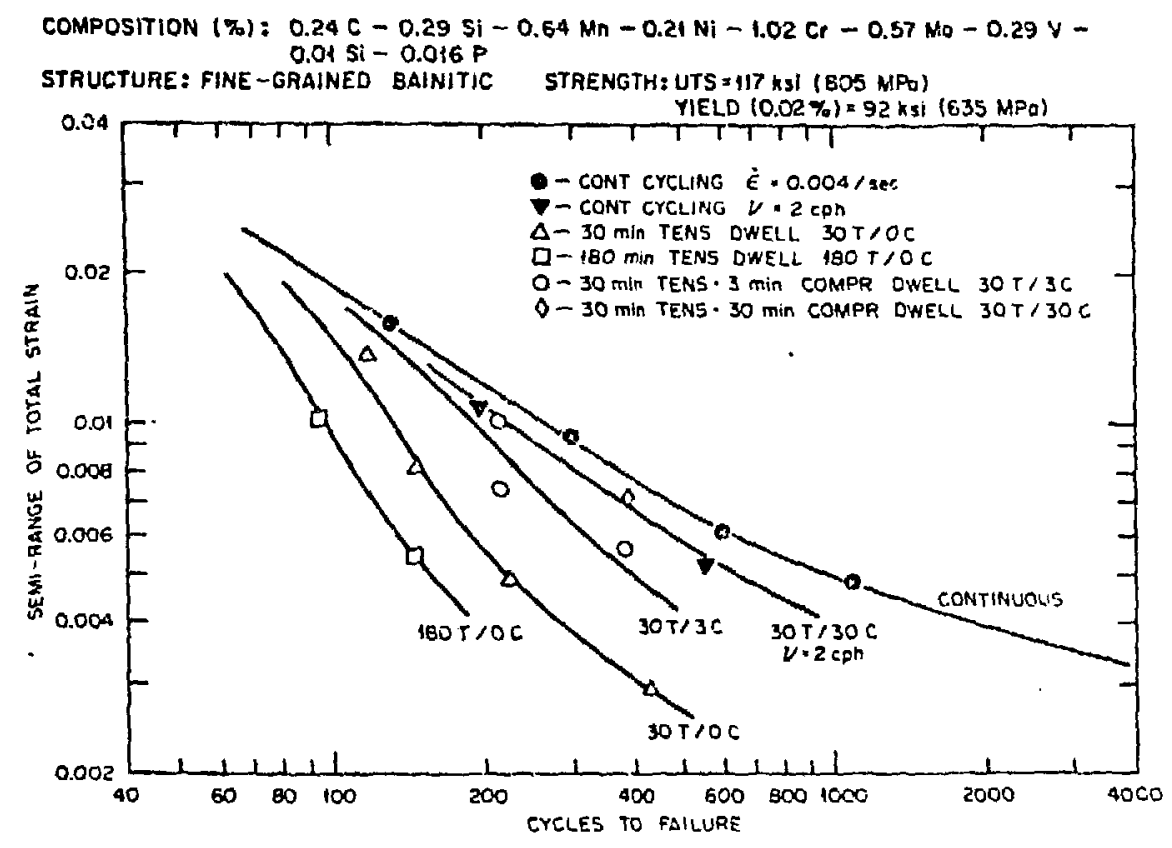

Fig. 8. Compression hold periods in conjunction with tensile hold periods improved the time-dependent fatigue behavior of a $1 \mathrm{Cr}-\mathrm{Mo}-\mathrm{V}$ steel at $565^{\circ} \mathrm{C}$. Source: E. G. Ellison and A.F.J. Patterson, "Behavior of a $1 \mathrm{Cr}-\mathrm{Mo}-\mathrm{V}$ Steel Subject to Combinations of Fatigue and Creep Under Stain Control," proc. Inst. Mech. Ens. Lonit: 190: 333-40 (1976) 


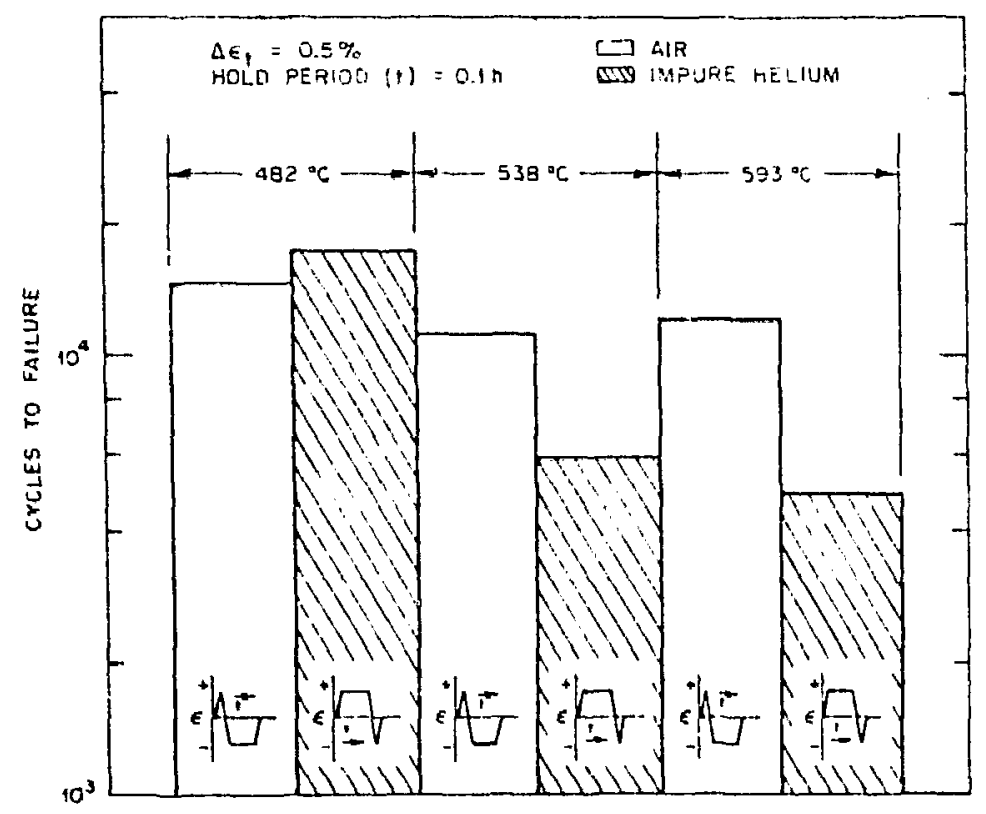

Fig. 9. Tensile hold times appear to be nore danaging than compressive hold times in inpure helium at temperatures equal to or in excess of $538^{\circ} \mathrm{C}$.

boundary cavitation was seen on both the circumferential surfaces (at 482 and $538^{\circ} \mathrm{C}$ ) (Fig. 11 ) and within the bulk (at $538^{\circ} \mathrm{C}$ ) (Fig. 12) of the tested specimens, demonstrating classical creep damage.

Exploratory time-dependent and strain-controlled tests similar to those previously discussed for type 304 stainless steel have also been conducted on annealed $21 / 4 \mathrm{Cr}-1$ Ho steel. Figure 13 summarizes some of the results from these exploratory tests. All the tests were run in strain control at a single strain range and temperature with a hold period introduced each cycle at a single point on the hystersis loop, as shown. The duration of the hold period was either 0 or $0.1 \mathrm{~h}$, as indicated. Results of these tests conducted in air demonstrate the following for the particular strain range and temperature shown:

1. Compression holds are nore damaging than tensile holds $(6,111$ vs 20,147 cycles to failure).

2. In comparison with zero hold-time or continuous cycle tests, tests cunducted with a hold period introduced at zerc stress points show decreased fatigue life: the average cycle life for 

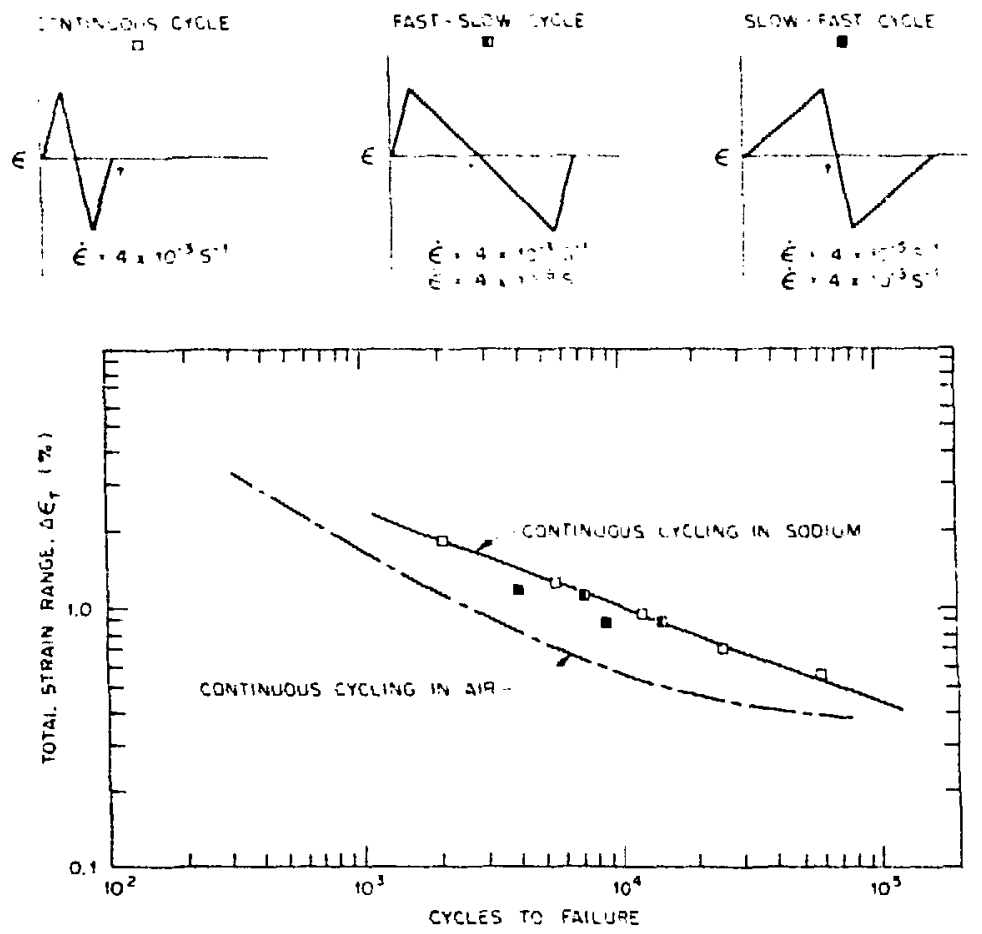

Fig. 10. Waveform is an important variable only in the slow-fast cycle for $21 / 4 \mathrm{Cr}-1$ Mo steel tested at $538^{\circ} \mathrm{C}$ in sodiua. Source: 0. K. Chopra, K. Natesan, and T. F. Kassner, "Influence of Sodium Environment on the Low Cycle Fatigue and Creep-Fatigue Behavior of $\mathrm{Fe}-21 / 4 \mathrm{Cr}-1$ lo Steel," paper presented at Second International Conference on Liquid Metal Technology in Energy Production, Richland, Washington, April 10-24, 1980.

three specimens subjected to continuous cycling at a strdin rate of $4 \times 10^{-3} / \mathrm{s}$ was 37,329 vs cycle lives of 6,317 and $15,55 ?$ for the zero stress points shown.

3. After continuous cycling at the indicated strain range, it was possible to locate points on the hysteresis loop in both tension and conpression where little or no stress relaxation occurred (Fig. 14). A point in compression was at approximately -190 Mpa for the conditions indicated in Fig. 13, ind the resultant fatigue life was 11,667 cycles to failure. This test again shows degradation in lifetime in comparison with the continuous cycle life at these conditions (i.e., 11,667 vs 37,329 cycles to failure). 


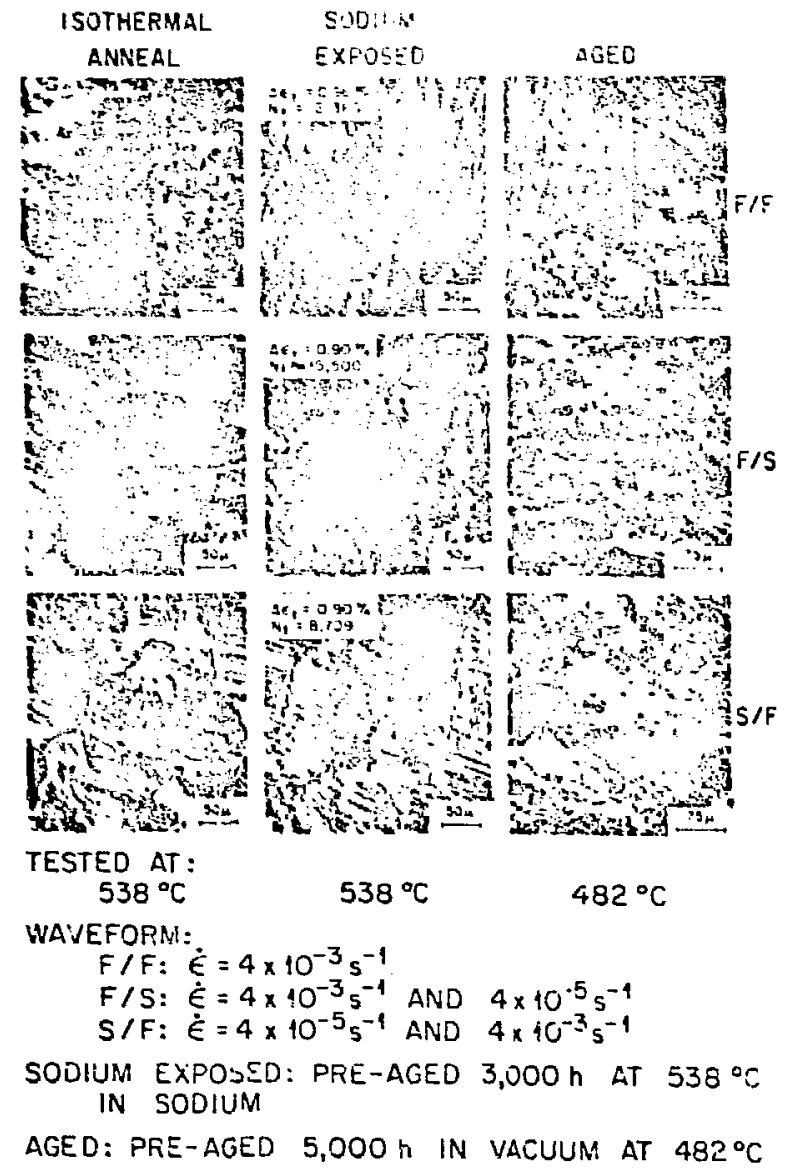

Fig. 11. Results of scanning electron microscope examination of the circumferential suriaces of specimers of Fe-2 1/4 Cr-1 Mo steel fatigue tested in sodiun. Note grain boundary cracks at boundaries perpendicular to direction of applied stress for slow-fast (S/F) saveform. Source: 0 . K. Chopra, K. Natesan, and T. F. Kassner, "Influence of Sodium Environment on the Low Cycle Fatigue and Creep-Fatigue Behavior of Fe-2 1/4 Cr-1 Mo Steel," paper presented at Second International Conference on Liquid Metal Technology in Eriergy Production, Richland, Washington, April 10-2/, 1980. 


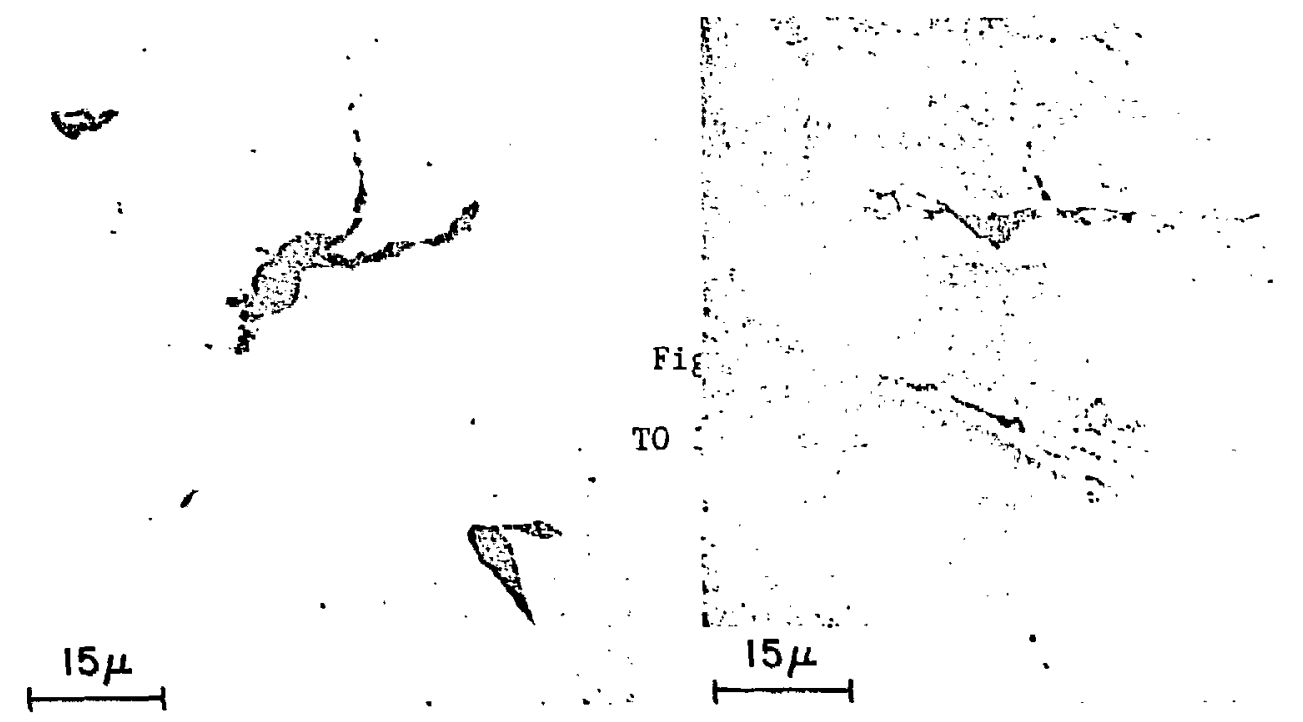

Fig. 12. Intergranular cavities were found in specimens of Fe-2 $1 / 4 \mathrm{Cr}-1$ Mo steel subjected to slow-fast waveform at $538^{\circ} \mathrm{C}$ in sodium. Cavities of this type were not found in specimens similarly tested at $482^{\circ} \mathrm{C}$. Source: 0. K. Chopra, K. Natcsan, and T. F. Kassner, "Influence of Sodium Enviroment on the Low Cycle Fatigie and Creep-Fatigue Behavior of $\mathrm{Fe}-21 / 4 \mathrm{Cr}-1 \mathrm{No}$ Steel," paper presented at Second International Conference on Liquid Metal Technology in Energy Production, Richland, Washington, April 10-24, 1980.

Examination of the surfaces of these specimens has shown that oxide interaction with the surface prociuces characteristic circumferential markings (Figs, 6 and 15), which are thought to decrease the rumber of cycles required for crack initiation with resultant reduction in cyclic life.17-19 These markings are absent on the surface of specimens tested in nonoxidizing environments (Figs. 11 and 16).

It should also be noted that a protective environment that limits or prevents oxidation also markedly decieases high tenperature crack propagation rates in comparison with data obtained in an air environment for this material. 22

Linear damage sumation of time and cycle fractions has been performed an the various tests shown in Fig. 13. The resultant $D_{t}$ or total dimage sumation values are all lass than 1.00 and tend not to sum to a unique value under strain or load-controlled conditions, making linear damage sumation a questionable method for extrapolation, at least for air environments. 


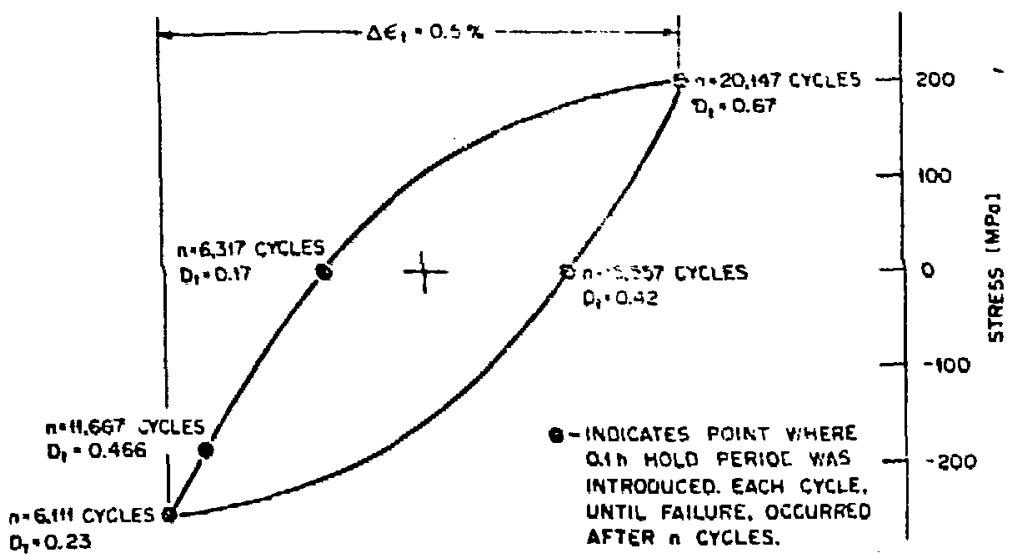

$\sum \frac{n}{N_{1}}+\sum \frac{1}{n_{1}} \cdot D_{T}$

$N_{1}=37.329$ CYCLES

$\log 1,+-13.32 \theta+6.3190 U / T+23349 / T-15693 . \theta / T 1100 \sigma$

U - ULTIMATE TENSILE STPENGTM (MPA), 410 MPO

$T$ - TEMPERATURE ( $\mathrm{A} X)$

$\sigma \cdot$ STRESS (MPa)

Fig. 13. Time and cycle fraction damage analysis for annealed

$21 / 4 \mathrm{Cr}-1$ Ho steel heat $3 P 5601$ tested at $482^{\circ} \mathrm{C}$ in air.

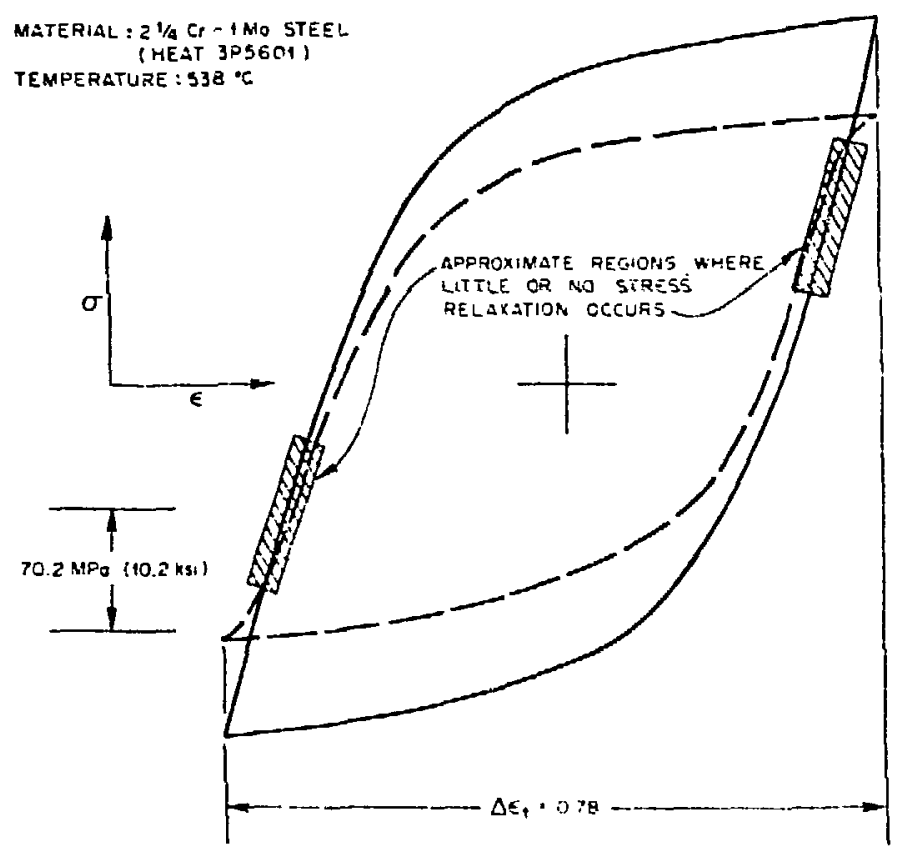

Fig. 14. Dashed lines represent locus of stress relaxation points following $0.1-h$ strain hold periods from various positions on the solid curve. Incersecting points represent positions of zero stress relaxation. 


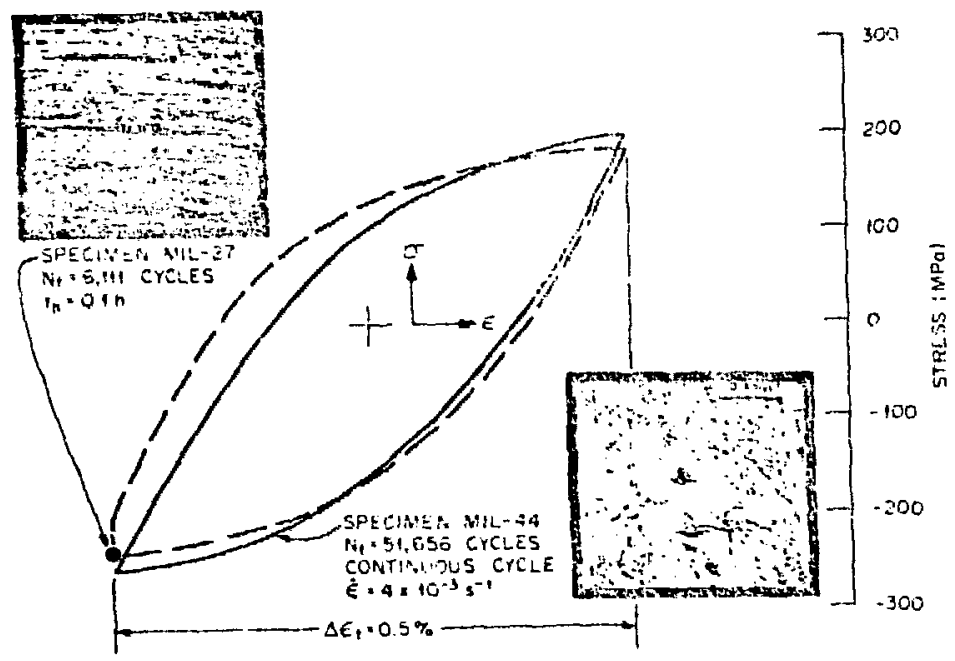

Fig. 15. Comparison of hysteresis loops, surfaces, and fatigue lives of two specimens subjected to strain control cycling at $482^{\circ} \mathrm{C}$. Note that specimen MIL-36 had a 0.1 -h hold period introduced each cycle at peak compressive strain.

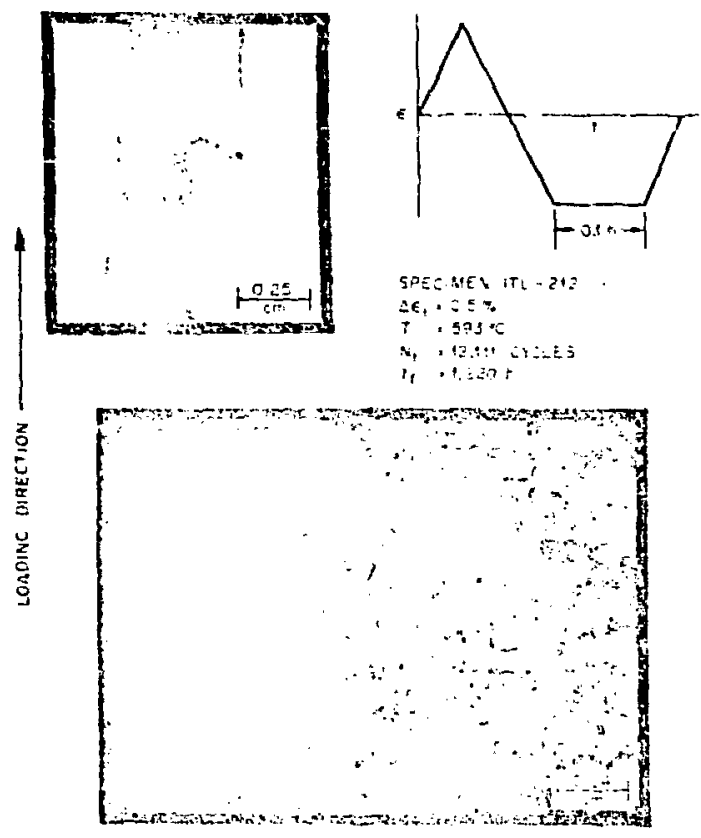

Fig. 16. The surface of a specimen of $21 / 4 \mathrm{Cr}-1$ Mo steel tested in inpure helium in strain control with a compression dwell period each cycle. 
EYY SE MENAI INTERACTION AND TIME-DEPENDENT FATIGUE

Ii $1 ! \ldots$ : $:$ IUIRATURE GAS-COOLED REACTOR SYSTEMS

\section{Alloy $800 \mathrm{H}$}

Gas-cooled nuclear reactors presently ulider consideration, in which the coolant or heat transfer medium is helium with low lavels of impurities, also require design for the prevention of timedependent fatigue. The helium enviroment may be oxidizing, reducing, carburizing, decarburizing, depending on the alloy involved, the temperature, the moisture content, and the carbon potential of the gas relative to the carbon activity of the meta1.23 An example 24 of the effects of impure heliun and air on the straincontrolled fatigue properties of alloy 80011 tested at 650 and $760^{\circ} \mathrm{C}$ is given in Table 1. A comparison of the data shown follows.

Table 1. Impure Helium Environments that Can Produce

Carburization Appear to Degrade Time-Dependent

Fatigue Life of Alloy $800 \mathrm{H}$ Subjected

to Tensile Hold Times ${ }^{a}$

\begin{tabular}{|c|c|c|c|c|c|}
\hline \multirow{2}{*}{$\begin{array}{l}\text { Temperature } \\
\left({ }^{\circ} \mathrm{C}\right)\end{array}$} & \multirow{2}{*}{$\begin{array}{l}\text { Strain } \\
\text { Range } \\
(\%)\end{array}$} & \multicolumn{2}{|l|}{ Hold } & \multicolumn{2}{|c|}{ Cycles to Failure } \\
\hline & & Mode & $\begin{array}{l}\text { Time } \\
(\min )\end{array}$ & Impure Heliumb & Air \\
\hline 650 & 0.4 & 0 & 0 & & $310^{6}$ \\
\hline 650 & 0.4 & Tension & 1 & 5,465 & 26,767 \\
\hline 650 & 0.4 & Tension & 2.5 & 3,629 & 14,790 \\
\hline 760 & 0.4 & Tension & 2.5 & 2,790 & 1,053 \\
\hline 650 & 0.4 & Compression & 1 & 10,672 & 13,000 \\
\hline 650 & 0.4 & Conpression & 2.5 & 10,308 & 8,836 \\
\hline 760 & 0.4 & Compression & 2.5 & 4,785 & 1,628 \\
\hline
\end{tabular}

aSource: D. I. Roberts, S. N. Rosenwasser, and J. F. Watson, "Materials Selection for Gas-Cooled and Pusion Reactor Applications," paper 9 presented at Conference on Alloys for the $80^{\prime} \mathrm{s}$, Ann Arbor, Michigan, June 17-18, 1980.

bHelium composition, ppm: $\mathrm{CH}_{4}=57 ; \mathrm{CO}=50 ; \mathrm{H}_{2}=500 ; \mathrm{H}_{2} \mathrm{O}=1$. 
1. ir $1 \mathrm{~cm}$ strain ranges compression hold periods are more damis ng than tensile holds at $650^{\circ} \mathrm{C}$ in air, but the reverse appear; tr be true at $760^{\circ} \mathrm{C}$.

2. Inpure helium appears to cause a marked decrease in the fatigue life of specimens subjected to tensile hold times in comparison with similar tests conducted in air at $650^{\circ} \mathrm{C}$. This is attribuced to carburization.

There are indications that the magnitude of the hold-time effect in strain-controlled tests is dependent upon temperature and strain range as well as upon the magnitude and direction of any mean stress that is developed during a given test.

ENVIRONMENTAL INTERACTION AND TIME-DEPENDENT FATIGUL:

IN FUSION REACTOR FIRST-WALL SYSTEMS

Cyclic thermal stresses will occur in first-wall and blanket materials of pulsed fusion power generating devices. Because of this, fatigue data are currently being generated on candidate materials, including cold-worked type 316 stainless steel, refractory alloys, and a number of martensitic low-alloy steels with chromium contents in the range 9 to $13 \%$. Environments or possible coolants associated with the first-wall and blanket structure may be liquid metals, gas, molten salts, or water. In addition, the first wall of a fusion reactor will also be subjected to intense high-energy neutron irradiation damage, causing atom displacement danage as well as helium and hydrogen generation.

The influence of high irradiation-induced helium contents and displacement damage on resultant tensile and fatigue properties of $20 \%$ cold-worked (20\% reduction in area by swaging) type 316 stainless steel is currently being investigated. 25 A plot showing the effects of high helium content, etc. on the resultant strain-controlled fatigue properties of type 316 stainless steel is given in Fig. 17. Note the high scatter in the irradiated data and the resultant overall degradation in fatigue life, particularly at the low cycle end of the curve. Tensile ultinate strengths and reduction of area values were approximately $614 \mathrm{MPa}$ and $36 \%$, respectively, in comparison with unirradiated values of $650 \mathrm{NPa}$ and $60 \%$, near the indicated temperature and irradiation conditions. Figure 18 is a transmission electron micrograph showing ext znsive helium bubbles within the microstructure. At higher temperature helium bubbles at grain boundaries are thought to be particularly deleterious because of the probability of increased intergranular crack propagation rates under cyclic loading conditions.26 Work dealing with the influence of irradiation on time-dependent fatigue properties, data analysis, and extrapolations has teen published elsewhere. 27 


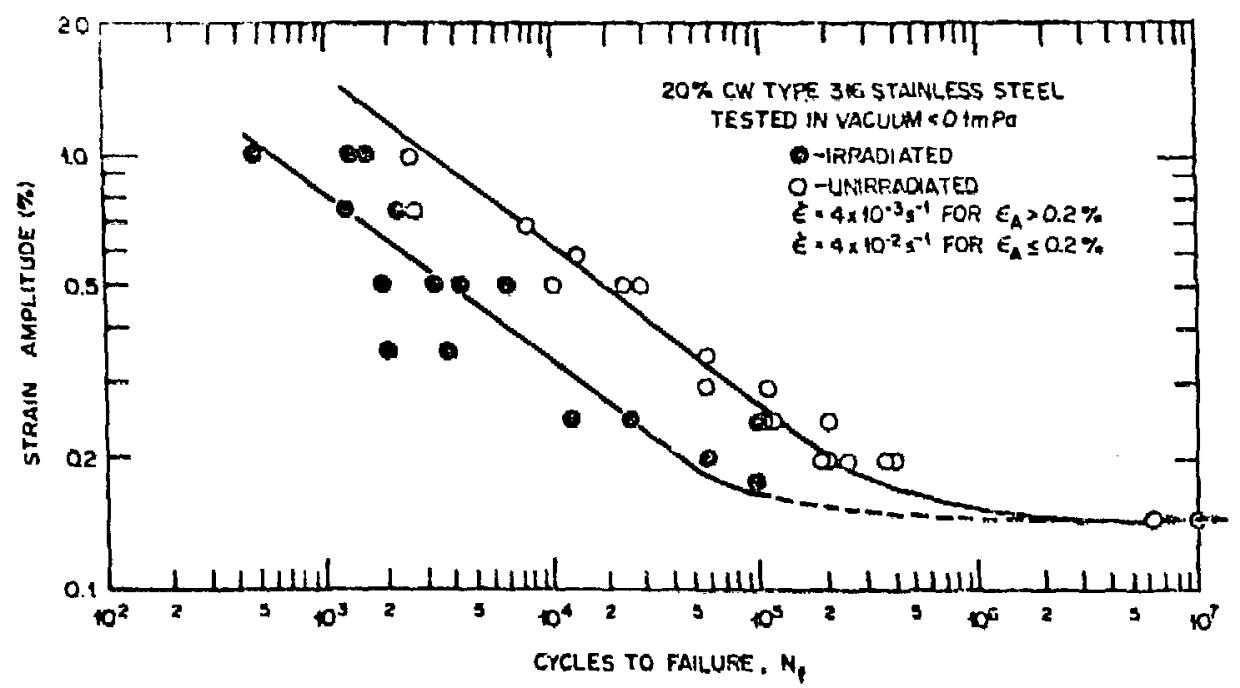

Fig. 17. Low cycle fatigue life is reduced by factors of 3 to 10 for 200 to $1000 \mathrm{ppm}$ He and 5 to 15 dpa at $430^{\circ} \mathrm{C}$, indicated endurance limit is at a strain amplitude of $0.15 \%$. Scurce: M. Lo Grossbeck and K. C. Liu, "Fatigue Behavior of Type 316 Stainless Steel Following Neutron Irradiation Inducing Heliun," paper presented at American Nuclear Society meeting, La Vegas, Nevada, June 8-13, 1980.

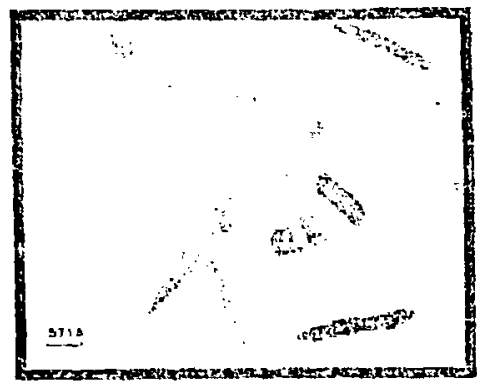

Fig. 18. Mcrostructure of $20 \%$-cold-wcrked type 316 stainless steel irradiated in the high Flux Isotope Reactor (HFIR) for $2,770 \mathrm{~h}$ at $470^{\circ} \mathrm{C}(12 \mathrm{dpa}, 540 \mathrm{at}$. prom He. Note the presence of helium bubbles randonly distributed throughout the matrix. Transmission electron nicrograph courtesy of P. J. Maziasz, Oak Ridge National Laboratory. 
SUMMARY ANiD CONCLUSIONS

Recently reported results iron a number of ongoing materials data gencrat no pograns were reviched. These programs are aimed

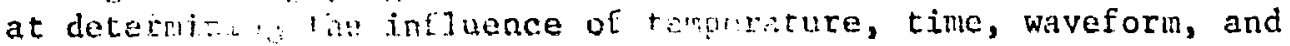
enviroumen: sh the ale"rated-temptu-ur. fatigue properties of severa] : * a d a presently $i$ il: use or planned for use in a number $\therefore$ tear power generating systems. Specific major $:$.

1.

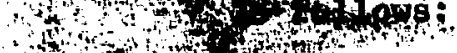

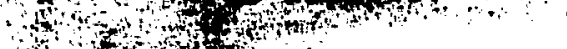

Howgen a

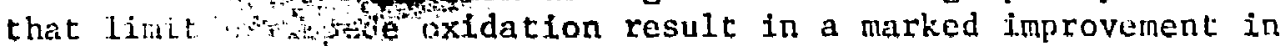
the continuous sycle fatigue life of types 304 and 316 stainless steel at temperatures within the creep range. However, when loading waveforue are employed such that intergranular crack propagation occurs, the differences .n fatigue life tend to be minimal. This finding, particularly for long-term test results, supports the concept of a true creep-fatigue effect as a major contribution to the observed decrease in cycle life.

2. Exploratory strain-controlled fatigue tests conducted on type 304 stainless steel in air have shown that some degradation in fatigue life in comparison with continuous cycle tests can occur when hold periods are introduced at aero stress or zero relaxation points on the hysteresis loor.u. Similar tests conducted on annealed $21 / 4 \mathrm{Cr}-1 \mathrm{Mc}$ steel in air and at low strain ranges tend to show significant degradation in cycle life. This has been attributed to wave-form-oxide interactjon that facilitates crack nucleation and accelerates crack propagation.

3. Cycle lives of specimens of $21 / 4 \mathrm{Cr}-1$ Mo tested in nonoxidizing environments, such as sodium, do not show the significant waveform dependency effects that arc found for similar tests in air. However, slow-fast triangular wayeforms at high temperature reduce cycle lives in sodiun probably from the generation of grain boundary voidage.

4. Limited results of strain-controlled time-dependent fatigue tests conducted on alloy $800 n$ in air have shown that the fatigue life is dependent upon cyclic waveform and strain range interaction and that a carburizing environment can be detrimental, depending again upon the cyclic waveform inposed.

5. Classical methods such as tine and cycle fraction summation for predicting or extrapolating data appear questionable, particularly at temperatures where there is stron, environmental interaction.

6. An example was selected for $20 \%$ cold-worked type 316 stainless steel to show that environments generated within a 
structural material, such as the inglicent damage and helium bubbles obtained by irradiation, nus: also be considered in design against fatigue demige when appropiate.

\section{REFERENCES}

1. K. Natesan, T. F. Kassner, and C. Y. Li, "Effect of Sodium on Mechanical Properties and Friction-Wear Behavior of LMFBR Materials," React. Technol. 15(4): 244-71 (1972-73).

2. W. Charnock, C. P. Haigh, C.A.P. Horton, and P. Marshall, Underwriting Structural Steels for the Sodium-Cooled Fast Reactor, No, 10, Central Electricity Generating Board Research, Uniled Kingdom, November 1979, pp. 3-14.

3. H. Huthmann, (V Menken, H. U. Borgstedt, and H. Tas, "Influence of Flowing Soltium on the Creep-Rupture and Fatigue Bchavior of Type $304 \mathrm{~S}$ :ainless Steel at $550^{\circ} \mathrm{C}$," paper presented at Second Internitional Conference on Liquid letal Technology in Energy Production, Richland, Washington, April 20-24, 1980.

4. A. R. Keeton and C. Bagnal1, Factors That Affect Corrosion in Sodiun," paper presented at Second International. Conference on Liquid Me-al Technology in Energy Production, Richland, Washington, April 20-24, 1980.

5. C. R, Brinkman, V. K. Sikka, and K. T. King, Mechanical Properties of LMFBR Primary Pipe Materials," Nucl. Techn']. 33(1): 76-15 (April 1977).

6. C. R. Brinkman, V. K. Sikka, and M. K. Booker, "Mn Overview of the U.S. Programs on Properties of Primary Circuit Materials," pp. 13-23 in Specialist Meeting on Primary Circuit Structural Materials Including Environmenta1 Effects, IWGFR/22, International Atomic Energy Agency/International Working Group on Fast Reactors, Bergisch Gladbach, Federal Republic of Germany, October 17-21, 1977.

7. P. S. Maiya, "Effects of Waveshape and Ultra-lljgh Vacuum on Elevated Temperature Low-Cycle Fatigue in Type 304 Stainless Stecl," submitted to Materials Science and Engineering.

8. K. Natesan, 0. K. Chopra, and T. F. Kassner, "Creep-kupture and Low-Cycle Fatigue Behavior of Types 304 and 316 Stainless Steel Exposed to a Sodiun Environment," paper presented at 2d International Conference on Liquid Metal Technology in Energy Production, Richland, Washington, Apri1 20-24, 1980.

9. L. F. Coffin, Jr., "The Effect of ligh Vacuun on the Low Cycle Fatigue Law," Netall. Trans. 3: 1777-78 (July 1972).

10. L. A. Janes, "Some Ruestions Regarding the Interaction of Creep and Fatigue," J. Eng. Mater. Technol. 235-43 (July 1976).

11. K. Sadananda and P. Shahinian, "Effect of Environment on irack Growth Behavior in Austenitic Stainless Steels Under Creep and Fatigue Conditions," Heta11. Trans. 11A: 267-76 (February 1980). 
12. Y. Asda and S. Mitsuhashi, "Ue. Matigue Interaction of 304 and 316 Stainless Steels in A.t and Vaculi.: paper presented at 4th International Conietence on Prussure Vessel Technology, London, England, May 19-23, inew.

13. D. J. Michal and H. H. . : : a, "Azcolerated Creep-Fatigue Crack Propagation in Therme 1.1\% Col Type 316 Stainless Steel," subnittad to icta Metallurgita.

14. P. Marsial1 and C. R. Brinkman, "lize Influence of Environment and Microstructure on Fatigue and Creep Crack Growth in Thick Section AISI Type 316 stainless Steol," paper presented at ASME Symposium on Material Environment Interactions in Structural and Pressure Containment Service, Chicago, Illinois, November $16-21,1980$.

15. C. R. Brinkman and M. Kaccher, "Materials Technology for Steam Generators in Liquid Metal Fast Breeder Reactor Systems," Met. Prog. 116(2): 54-61 (July 1979).

16. C. R. Brirkman, J. P. Strizak, and M. K. Booker, "Experiences in the Use of Stralnrange Partitioning for Pedicting Time-Dependent Strain-Controlled Cyclic Lifetimes of Uniaxial Specimens of $21 / 4 \mathrm{Cr}-1$ Mo Steel, Type 316 Stainless Steel, and Hastelloy $x, "$ pp. 15-1-15-1S in Characterization of Low Cycle High Temperature Fatigue by the Strainrarge Partitioning Method, AGARD Conf. Proc. 2/3, Technical Editjng and Reproduction, Ltd., Harford house, London, April 1978.

17. C. R. Brinkman, J. P. Strizak, M. K. Booker, and C. E. Jaske, "Time-Dependent Strain-Controlled Fatigue Behavior of Annealed $21 / 4 \mathrm{Cr}-1$ Mo Stcel for Use in Nuclear Stean Cenerator Design," J. Nucl. Hater. 62(2,3): 181-204 (November 1976).

18. K. D. Challenger, A. K. Milier, and C. R. Brinkman, "ElevatedTemperature Fatigue with Hold Time in a Low Alloy Steel:

Creep Damage or Environtental Damage? Part I - Physical Mechanisms," submitted to Journal of Engineering Materials and Technology, 1979 .

19. H. Teranishi and A. J. McEvily, "rhe Effect of Oxidation on Hold Time Behavior of $21 / 4 \mathrm{Cr}-1$ Mo Steel," to be published in Metall. Trans.

20. E. G. Ellison and A.J.F. Patterson, "Behavior of a $1 \mathrm{Cr}-\mathrm{Mo}-\mathrm{V}$ Steel Subject to Combinations of Fatigue and Creep Under Strain Control," Proc. Inst. Mech. Eng. London 190: 333-40 (1976).

21. 0. K. Chopra, K. Natesan, and T. F. Kassner, "Influence of Sodiun Envirotment on the Low Cycle Fatigue and Creep-Fatigue Behavior of $\mathrm{Fe}-21 / 4 \mathrm{Cr}-1$ Mo steel, " paper presented at Second International Conference on Liquid Metal Technology in Energy Production, Richland, Washington, April 20-24, 1980.

22. C. R. Brinkman, M. K. Booker, J. P. Strizak, zind T. Weerasooriya, "Fatigue Behavior of $21 / 4 \mathrm{Cr}-1$ Mo steel in Support of Steam Generator Development," pp. 59-72 in Time 
a1: 1 at !ependent Degradation of Pressure Boundary Materials, un Austia, November 20-21, 1978, International Atonic r. Agency, IWG-RRPC-79/2.

23. D. T. Roherts, S. N. Rosenwasser, and J. F. Watson, "Materials Selection for Gas-Cooled and Fusion Reactor Applications," paper presented at Conference on Alloys for the 80 's, Ann Arbor, Michigan, June 17-18, 1980.

24. Personal commication, J. L. Kaae, Ceneral Atomic Co., La Jolla, Calif., June 1980.

25. M. L. Grossbeck and K. C. Liu, "Fatigue Behavior of Type 316 Stainless Steel. Following Neutron Irradiation Inducing Heliun," paper presented at the American Nuclear Society meeting, Las Vegas, Nevada, June $8-13,1980$.

26. M. L. Grossbeck and P. J. Maziasz, "Tensile Properties of Type 316 Stainless Steel Irradiated in a Simulated Fusion Reastor Environment," J. Nuc]. Mater. 85 and 86(II,B): 883-87 (1979).

27. C. R. Briukman, K. C. Liu, and M. L. Grossbeck, "Estinates of Time-Jependent Fatigue Behavior of Type 316 Stainless Steel Subjent to Irradiation Damage in Fast Breeder and Fusion Power keactor Syctems," Pp. 490-510 in Effects of Radiation on Structural Malez:als, ASTM Spec. Tech. Publ. 683, J. A. Sprague and D. Kramer, Eds. American Society for Testing and Naterials, Philadelphia, 1978. 